\title{
Social Media Usage Practices of Luxury Brands: A Case of Luxury Automobile Brands' Corporate Social Media Applications
}

\author{
Sevilay Ulas \\ Near East University, CYPRUS \\ (iD) 0000-0002-0137-1263 SC 55789510800 C-7966-2019 \\ sevilay.ulas@neu.edu.tr
}

\section{Zekiye Beril Akinci Vural}

Ege University, Faculty of Communication, İzmir, TURKEY

(D) 0000-0002-4902-4973 SC 36452065100 D D-3020-2019

ARTICLE INFO

Received: 24 January 2019

Accepted: 4 February 2019

Published: 26 February 2019

DOI: https://doi.org/10.29333/ojemt/5723

ABSTRACT

Purpose: The main purpose of this study is to determine the luxury brands' practices of using social media environments at the corporate level.

Methodology: In this study, corporate official social media accounts of the luxury brands have included based on the list which were examined according to the luxury brand research report by Luxurysociety.com called as "Best Global Luxury Brands". Significantly, this report was realized worldwide and included all product groups of 2014 luxury brands with social media applications, so in this study Turkey was selected. All of the specified brands are car brands and are listed as Mercedes-Benz, BMW, Audi, Porsche, and Land Rover. In all of these specified luxury brands, content analysis was conducted for shared corporate social media accounts. A study covering one (1) year of content sharing in the social media environments, from 01.02.2016 to 01.02.2017.

Results: As a result of the content analysis, social media usage practices of these luxury car brands, it is seen that they share their corporate identity in their official Facebook accounts, but mission and vision sections are more limited in terms of their content. In addition to these, it has been seen that brands use social media more intensively in new products / series promotions, creating interest in product categories, introducing new technologies of their products and introducing accessories / promotions related to the brand in comparison to other headings in the category chart. Their Instagram shares during the chosen period of time, we see shares of contents about the corporate achievements / news, special day / national holiday celebrations, the technical infrastructure of the products, the brand's corporate-level activities, the events they organize in the Instagram account for customers and followers in each brand.

Conclusion: In social media usage practices of these brands, it was observed that there are activities (such as drawing, contest) organized in social media environments to create new ways of reaching consumers and followers, as well as marketing-oriented shares about activities (such as corporate social responsibility, other institutional activities) that are realized at the brand's corporate-level.

Keywords: luxury brands, social media, luxury car brands, luxury brand communication 


\section{INTRODUCTION}

In this new communication environment, it can be said that, like all brand groups, the involvement of luxury brands in social media environments and their interaction with their followers, to be able to access these luxury brands that are wondered about and often unreachable in social media environments started a different period in the communication of luxury brands with their target audience and followers. It is becoming increasingly important to identify the ways in which luxury brands present themselves in the corporate dimension, the ways in which they interact with their followers, the content they share about their brands and determining the customers' brand-related and personal practices of using social media, and to develop the right strategies in this direction.

\section{LUXURY BRANDS}

It can be said that the concept of luxury extends to the earliest civilizations. There are definitions which include different characteristics of the concept of luxury. In its simplest form, according to the definitions stated in Turkish Language Association, luxury is expressed as showy, gaudy, out of necessity, (http://www.tdk.gov.tr/index.php?option=com _gts\&arama=gts\&guid=TDK.GTS.5b1f7a93371f56.47236444). On the other hand, there is another definition that emphasizes luxury as 'a state of great comfort or elegance, especially when involving great expense' (https://en.oxforddictionaries.com/definition/ luxury).

The concept of luxury brand which comes with luxury product is also among the brand types. Nueno and Quelch (1998) mention that Latin word luxus, means indugence of the senses, regardless of cost. Luxury brands are those whose ratio of functional utility to price is low while the ratio of intangible and situational utility to price is high. Today, it is seen that luxury brands have traditional values, even though there is a number of innovations and changes in the markets, communication activities and also consumers. Table 1 contains a number of characteristic features of luxury brands (Nueno \& Quelch, 1998: pp. 62-63).

Table 1. Different Definition and Meaning of Luxury Brands

consistent delivery of premium quality across all products in the line, from the most to the least expensive;

a heritage of craftsmanship, from the original designer (Tiffany's, for example, is 160 years old);

a recognizable style or design (the savvy consumer does not need to look at the label to know the brand);

a limited production to ensure exclusivity and possible to generate a customer waiting list;

a marketing program that supports, through limited distribution and premium pricing, a market position that combines emotional appeal with product excellence;

a global reputation (the brand's world-class excellence is universally recognized);

association with a country of origin that has an especially strong reputation as a source of excellence in the relevant product category;

an element of uniqueness to each product (the imperfections in each hand-blown Wdterford crystal vase provide, ironically. the assurance of exclusivity);

an ability to time design shifts when the category is fashion-intensive;

the personality and values of its creator.

Source: Jose Luis Nueno and John A. Quelch, 1998: 62-63. The Mass Marketing of Luxury Business Horizons / November-December.

\section{LUXURY AND SOCIAL MEDIA}

It may not be possible to say that luxury brands and social media environments can warm up to one another as easily as other brands. Luxury brands are expected to evoke uniqueness and exclusivity through high quality, premium pricing, and controlled 
distribution. Until today, the primary channel of retailing has been the luxury brands, with the uniqueness and exclusivity of strictly controlled distribution, however, along with the dramatic rise in social media environments, luxury brands faced the effects of social media applications. In this sense, luxury brands face challenges in how they maintain and present their core values, in brand communication (Jin, 2012: pp. 687-688).

In last decades, the usage practices of social media in personal and brand communication activities are figured out. In this sense, after the development of web 2.0 which ensures interactive communication, as brand communication period, social media has become much dominant in people's lives (Eginli \& Tas, 2018: p. 81). It is important to say that social media and its creativity opportunities are very crucial for providing the platform for enlarging the awareness amongst the followers, that pushes more creative culture to capture the attention. Therefore, new trends in social media sharing has started to main object of different social network users (Ciftci \& Evren, 2018: p. 386 cited in Meikle, 2016, p. 17). Relatively, in recent years, luxury brands also put much effort on carrying out communication activities in social media tools and applications. At this point, effective communication activities of luxury brands in social media draw attention. For example, traditional designer houses such as Louis Vuitton provide live broadcasting fashion shows on their blogs. Ralph Lauren, Chanel, Donna Karan, and Gucci have worked with Apple to create IPhone applications (Kim \& Ko, 2012: p. 1480). During luxury brands' marketing communication activities, it can be seen that luxury brands mainly try to not only build but also maintain a strong and long run relationships with their customers (Kim \& Ko, 2010: p. 166). In her article entitled by Luxury Brands on Social Media, Rachel Weaver stated that social media could be accepted as a relatively new frontier for luxury brands. Table 2 illustrates the number of activities carried out by luxury brands in social media environments.

Table 2. An Example of Social Media Applications of Luxury Brands

\begin{tabular}{|c|c|c|}
\hline Luxury Brand & Social Media & Social Media Applications \\
\hline Louis Vuitton: & Instagram & $\begin{array}{l}\text { LV's most successful posts on Instagram come primarily from images of new } \\
\text { products and designs. This takes advantage of connections with popular digital } \\
\text { influencers. }\end{array}$ \\
\hline Chanel: & & $\begin{array}{l}\text { Chanel started its Instagram, accumulated followers, and had a substantial amount } \\
\text { before publishing a single post. Chanel understands this and implemented the } \\
\text { strategy by using GIF images that catch the viewer's eye with small amounts of } \\
\text { motion. }\end{array}$ \\
\hline Louboutin: & & $\begin{array}{l}\text { Louboutin's as a luxury brand, it is using Instagram to connect on a deeper level } \\
\text { with customers. Its goal is to sell an ideal rather than a specific product. }\end{array}$ \\
\hline Louis Vuitton: & Facebook: & $\begin{array}{l}\text { Louis Vuitton has been consistently visible across all channels and have almost } 18 \\
\text { million fans on Facebook and curate posts with lots of crisp, colorful pictures. }\end{array}$ \\
\hline Gucci: & & $\begin{array}{l}\text { Gucci's strategy on social media has focused on ad videos and special campaigns. } \\
\text { The brand was also sure to highlight anniversaries of well-known products to help } \\
\text { customers remember the brand's history. }\end{array}$ \\
\hline Dior: & & $\begin{array}{l}\text { Dior's Facebook is full of posts involving images with beautiful aesthetics. The } \\
\text { Facebook strategy has stayed in line with this brand ideal, wealth of gorgeous } \\
\text { images, Dior frequently posts videos, further engaging its audience. }\end{array}$ \\
\hline Chanel: & Twitter & $\begin{array}{l}\text { Chanel's Twitter strategy is beautifully shot short brand videos. These show a side } \\
\text { of the brand that resonates with viewers, and videos evoke more emotion than } \\
\text { photos because they involve motion and sound. }\end{array}$ \\
\hline Dior: & & $\begin{array}{l}\text { Dior's Twitter is flooded with stunning red carpet shots, product videos, and special } \\
\text { event recaps. The brand also gets a lot of traffic from campaigns such as "Lady } \\
\text { Dior." }\end{array}$ \\
\hline Louis Vuitton: & & $\begin{array}{l}\text { LV's Twitter highlights celebrities wearing Louis Vuitton items on red carpets for } \\
\text { high profile events. By interacting with and tagging celebrities, more users are } \\
\text { reached. }\end{array}$ \\
\hline
\end{tabular}


There are also differences in the communication environment that exists with social media environments, both in terms of its characteristics and consumers. In conjunction with social media, it can be said that only followers of brands among the whole communities are the target audiences. It can be said that there is a change or difference in the communication activities of the luxury brands with regards to the digital generation. At this point, luxury brands have been quick to embrace to engage digitallysavvy, mobile-dependent customers. In this sense, the next generation of millennials and Generation $\mathrm{Z}$ consumers are beginning to become more prominent in the market. Millennials expected to make up the dominant global workforce by 2020 . They are demanding newness, insight access and seamless service from luxury brands and retailers. This new approach to luxury shopping is giving rise to a new wave of retail, that's powered by social media (https://www.luxurysociety.com/en/articles/2018/05/socialmedia-powering-new-retail-wave/).

\section{RESEARCH SUBJECT \& PURPOSE}

Social media environments, which have become a new and effective channel especially in the process of luxury brand communication, have also created different application areas at the corporate level. Determining luxury brands' practices of using social media environments at the corporate level constitutes the main subject of the research.

\section{METHODOLOGY OF THE RESEARCH}

Content analysis method, which is one of the qualitative methods, will be applied in order to reveal the luxury brands' practices of using social media environments during the communication process at the corporate level. With content analysis, the shares of luxury brands in the relevant social media environments will be evaluated more meticulously from the corporate window. The main goal in content analysis is to reach the concepts and relationships that can explain the collected data. In content analysis, these concepts and previous comments, data, are subjected to a deeper processing. In this way, concepts that couldn't be noticed and important points captured can be discovered as a result of this analysis. In addition, with the ability to convert the non-verbal document of content analysis into quantitative data, it is more consistent to read and interpret the data obtained by the results being presented in the form of frequency and/or percentage tables (Balc1, 2011: p. 230). In the scope of this method, the documentation review was carried out in the collection of data. Document review involves the analysis of written documents containing information about the phenomenon or cases that are intended to be investigated. That being said, while document review can be used as a standalone research method, when used in conjunction with other research methods, it also provides important content as a source of additional information (Yıldırım \& Şimşek, 2013: p. 217). Within the qualitative method, the content analysis method will be carried out on luxury brands' shares in the corporate social media environments they use in Turkey in the research sample. For content analysis, firstly, which social media environments luxury brands within the sample group actively use will be determined and then, it will be carried out through the corporate social media accounts they actively use in our country. For content analysis, brands' purpose of using social media accounts, their shares, were examined one by one, an encoding heading was created for each social media environment and a coding schedule for the research was formed, along with the coding scale used. The pattern of the research was determined as case study pattern from qualitative research patterns. The most essential feature of the qualitative case study is the in-depth 
investigation of one or more cases. That is, the factors related to a situation (such as the environment, the individual, the events, etc.) are investigated by a holistic approach and focused on how they affect the relevant situation and how they are affected by it (Yıldirım \& Şimşek, 2013: p. 83).

A study covering one (1) year of content sharing in the social media environments of the brands studied was conducted. As a result, it has been observed that there are shares concentrated in different areas at every period of the year. The fact that the sample group is a car brand is a factor that actually supports this result. As encountered in this study, they share things with the campaigns and activities they implement during certain periods of the year. From this point on, the content analysis on the five (5) luxury car brands in the sample group was carried out on their corporate Facebook and Instagram accounts, which are common to all of them for a period of one (1) year from 01.02.2016 to 01.02.2017.

\section{CODING SCHEDULE}

In the content analysis carried out during the qualitative part of the research, coding schedules were created for the official Facebook and Instagram accounts of the related brands. The coding schedule for content analysis for the Facebook environment has been developed utilising category charts used in studies of Waters et al. (2009: p. 104) "Engaging Stakeholders Through Social Networking: How Nonprofit Organizations are Using Facebook" and Akyol et al (2014: pp. 126-129) Visual Communication in New Media Tools: An Investigation on the Social Media Usage of Automobile Brands". The coding schedule to be used in the Instagram account is based on coding scheme used in the studies of Ahmed et al. entitled as "A Picture tells a thousand words: A content analysis of concussion-related images online. Physical Therapy in Sport" (Ahmed et al., 2016: pp. 84-85). As a result of the review, the use of all the luxury brands featured in the sample on Facebook, Twitter, Instagram, Pinterest and Google+, which are common social media environments for these brands, was filtered and as a result, it has been determined that these brands use both Facebook and Instagram social media environments effectively in our country.

\section{BRANDS STUDIED IN RESEAR CH}

The universe of the research comprised the luxury brands listed in the research reports as known as the 2014 Best Global Luxury Brands which is a rare study and considered to be the most inclusive and including all luxury brands and product groups worldwide published on Luxurysociety.com Table 3 shows the luxury brand rankings covering the research universe. 
Ulas \& Akinci Vural

\begin{tabular}{lcccc} 
Table 3. World Wide Top Luxury Brand Rankings & & \\
\hline 2014 Rankings & Brand & $\begin{array}{c}\text { Brand Value } \\
\text { Million } \$\end{array}$ & $\begin{array}{c}\text { Brand Value } \\
\text { Development \% }\end{array}$ & 2013 Rankings \\
\hline \#10 & Mercedes-Benz & $34,338 \$$ & $\uparrow+\% 8$ & $\# 11$ \\
\#11 & BMW & $34,214 \$$ & $\uparrow+\% 7$ & $\# 12$ \\
\# 19 & Louis Vuitton & $22,522 \$$ & $\downarrow-\% 9$ & $\# 17$ \\
\# 41 & Gucci & $10,385 \$$ & $\uparrow+\% 2$ & $\# 38$ \\
\# 45 & Audi & $9,831 \$$ & $\uparrow+\% 27$ & $\# 51$ \\
\# 46 & Hermes & $8,977 \$$ & $\uparrow+\% 18$ & $\# 54$ \\
\# 58 & Cartier & $7,449 \$$ & $\uparrow+\% 8$ & $\# 64$ \\
\# 60 & Tiffany \& Co & $7,171 \$$ & $\uparrow+\% 11$ & $\# 72$ \\
\# 70 & Porsche & $5,977 \$$ & $\uparrow+\% 9$ & $\# 75$ \\
\# 71 & Prada & $5,936 \$$ & $\uparrow+\% 8$ & $\# 77$ \\
\# 73 & Burberry & $5,594 \$$ & $\uparrow+\% 9$ & \# \\
\# 91 & Ralph Lauren & $4,979 \$$ & & New \\
\# 97 & Land Rover & $4,473 \$$ & & New
\end{tabular}

Source: http://luxurysociety.com/articles/2014/10/2014s-best-global-luxury-brands

In this part of the study, criterion sampling was used from purposeful sampling method. The basic understanding of this sampling method is studying all situations that meet a set of predefined criteria. This criterion can be created by the researcher or a predefined criteria list can be used (Yıldırım \& Şimşek, 2013: p. 140). At this point, a preliminary study was carried out on the social media environments used by the luxury brands that make up the research universe and social media applications they use in Turkey were determined. These brands are specified as Mercedes Benz, Land Rover, BMW, AUDI and Porsche car brands. Sample of the study consists of luxury brands which have corporate social media accounts and at the same time included in this list.

\section{LIMITATIONS OF THE RESEARCH}

The limitations of the research can be grouped under the following headings:

- There is a limited number of studies on the use practices of luxury brands in social media environments.

- Luxury brands are more limited in number and cautious in social media environments than easily accessible brands.

- Investigation of corporate social media accounts used actively by these brands in the sample group determined within the framework of the research only in Turkey.

\section{FINDINGS RELATED TO QUALITATIVE PROCESSES}

The coding Scheme applied in the qualitative section of the research and the findings obtained are shown in Table 4. 
Online Journal of Communication and Media Technologies, 2019

Table 4. Findings for Official Facebook Accounts

\begin{tabular}{|c|c|c|c|c|c|}
\hline \multicolumn{5}{|c|}{ Facebook Page Content } & \multirow[b]{3}{*}{ Land Rover } \\
\hline \multirow[t]{2}{*}{ Categories } & \multicolumn{4}{|c|}{$\begin{array}{l}\text { Brand Names } \\
\end{array}$} & \\
\hline & Mercedes-Benz & BMW & Audi & Porsche & \\
\hline Follower / Visitor & $1,988,008$ & $1,189,996$ & $1,164,162$ & 111,524 & 378,914 \\
\hline Shared Total Content & 321 & 194 & 266 & 176 & 159 \\
\hline Shared Total Photos & 257 & 169 & 221 & 115 & 134 \\
\hline Shared Total Videos & 64 & 25 & 45 & 61 & 25 \\
\hline About & Present & Present & Present & Present & Present \\
\hline Mission \& Vision & Present & Present & Present & Absent & Present \\
\hline URL & Present / 39 & Present / 24 & Present / 41 & Present / 7 & Present/17 \\
\hline Contact & Present & Present & Present & Present & Present \\
\hline Visual Design Element & Present / 11 & Present / 6 & Absent & Absent & Absent \\
\hline Commemoration of the Founders & Present / 1 & Absent & Absent & Present / 2 & Absent \\
\hline Logo/Logo Design & Present / 5 & Absent & Absent & Present / 1 & Absent \\
\hline Status Messages & Present / 7 & Present / 4 & Present / 6 & Present / 5 & Present / 5 \\
\hline Special Days/National Holidays & Present /14 & Present / 10 & Present / 11 & Present / 9 & Present / 13 \\
\hline \multirow[t]{2}{*}{ Corporate Magazine / Publication } & Present / 2 & Absent & Absent & Absent & Absent \\
\hline & \multicolumn{4}{|c|}{ Content for Product Promotion } & \\
\hline \multirow[t]{2}{*}{ Categories } & \multicolumn{4}{|c|}{$\begin{array}{ll}\text { Brand Names } \\
\end{array}$} & \multirow[b]{2}{*}{ Land Rover } \\
\hline & Mercedes-Benz & BMW & Audi & Porsche & \\
\hline New Product Introduction & \multirow{2}{*}{$\begin{array}{c}\text { Present } / 23 \\
\text { Absent }\end{array}$} & \multirow{2}{*}{$\begin{array}{l}\text { Present / } 22 \\
\text { Present / } 1\end{array}$} & \multirow{2}{*}{$\begin{array}{l}\text { Present / } 6 \\
\text { Present / } 1\end{array}$} & Present / 21 & Present / 8 \\
\hline $\begin{array}{l}\text { Explaining the New Benefits of } \\
\text { the Old Product }\end{array}$ & & & & Absent & Absent \\
\hline $\begin{array}{l}\text { Creating An Interest for Product } \\
\text { Category }\end{array}$ & Present / 42 & Present /79 & Present / 41 & Present / 27 & Present /100 \\
\hline $\begin{array}{l}\text { Redirecting to online } \\
\text { store/product promotions }\end{array}$ & Absent & Absent & Absent & Absent & Absent \\
\hline Press Bulletin & Absent & Absent & Absent & Absent & Absent \\
\hline $\begin{array}{l}\text { New technology belonging to } \\
\text { products }\end{array}$ & Present / 2 & Present / 24 & Present / 2 & Present / 6 & Absent \\
\hline $\begin{array}{l}\text { Historical Background Of The } \\
\text { Products }\end{array}$ & Present / 5 & Present / 1 & Absent & Present / 22 & Present / 2 \\
\hline Product Advertising & Absent & Present / 2 & Absent & Present / 5 & Present /3 \\
\hline $\begin{array}{l}\text { Different product / accessory } \\
\text { promotions of the brand }\end{array}$ & Present / 9 & Present / 5 & Present /3 & Present / 6 & Present / 6 \\
\hline Forwarding to the Website & Present / 10 & Present / 3 & Absent & Present / 6 & Absent \\
\hline & Content For Ma & eting Suppor & & & \\
\hline Categories & & Brand & ames & & \\
\hline & Mercedes-Benz & BMW & Audi & Porsche & Land Rover \\
\hline Post Like & $1,703,231$ & $1,884,631$ & $1,723,399$ & 230,029 & 741,072 \\
\hline Post Comment & 26,088 & 18,608 & 22,186 & 2136 & 4603 \\
\hline Post Sharing & 45,529 & 39,523 & 52,910 & 6110 & 14,108 \\
\hline View Message & $18,067,485$ & $2,079,077$ & $11,857,900$ & $2,904,300$ & $1,597,800$ \\
\hline $\begin{array}{l}\text { Creating new ways of reaching } \\
\text { consumers (competition, } \\
\text { drawing, etc.) }\end{array}$ & Present / 31 & Present / 19 & Present / 33 & Present / 5 & Present / 22 \\
\hline Sponsorship Activities & Present / 9 & Absent & Present / 2 & Absent & Absent \\
\hline $\begin{array}{l}\text { Campaign Announcements } \\
\text { (sales, discount, etc.) }\end{array}$ & Present / 15 & Present / 1 & Present / 5 & Present / 3 & Present / 5 \\
\hline $\begin{array}{l}\text { Events (festivals, CSR, corporate } \\
\text { events, etc.) }\end{array}$ & Present/ 40 & Present / 24 & Present / 10 & Present / 8 & Present / 2 \\
\hline Corporate Achievement / Award & Present / 12 & Absent & Absent & Present / 7 & Present / 2 \\
\hline & Content For S & es Support & & & \\
\hline Categories & & Brand & nes & & \\
\hline & Mercedes-Benz & BMW & Audi & Porsche & Land Rover \\
\hline $\begin{array}{l}\text { Creating Store / Showroom } \\
\text { Traffic }\end{array}$ & Present / 10 & Present / 2 & Present / 12 & Absent & Present / 3 \\
\hline $\begin{array}{l}\text { Test Drive Experience / } \\
\text { Invitation }\end{array}$ & Present / 3 & Present / 7 & Absent & Present / 4 & Present / 1 \\
\hline Product Designer Stories & Absent & Absent & Absent & Absent & Absent \\
\hline $\begin{array}{l}\text { Redirecting to Online service } \\
\text { (promotion etc.) applications }\end{array}$ & Present / 5 & Absent & Absent & Present / 3 & Absent \\
\hline
\end{tabular}


Below are the evaluations related to the content sharing of these brands regarding the titles in the coding schedule applied within the scope of the research.

About Us section:

- There is an About Us section on the official Facebook ${ }^{\mathrm{TR}}$ page of Mercedes-Benz. In the corporation information section under the heading About Us establishment date of Mercedes-Benz brand is included. Within the mission part of the same category, there is information about the corporation. In this section, shares such as "Welcome to the Mercedes-Benz Facebook page where Mercedes-Benz fans and lovers meet. Join us to share your passion for Mercedes-Benz, your opinions about the products and services. On our page you can find the most up-to-date information about the world of Mercedes-Benz" were observed. Under Contact, another heading in this category, corporate web page address and a link which enables communication with the brand in the online environment are included.

- There is an About section on the official Facebook ${ }^{\mathbf{T R}}$ page of BMW. Under the heading About, in the corporate information section, only the information that it was established in 1916 was shared. In the Mission section: It is stated that this page is the Official Facebook page of BMW Turkey and BMW enthusiasts, fans and drivers in Turkey and it is seen that it offers news, information and a variety of entertainment related to the brand. It is seen that there is no information shared about the mission and vision information of the corporate brand. There are also shares in the contact information section. These are included as the Messenger link @BMWTurkiye to which messages can be sent, and http://www.BMW.com.tr. In the More information section; About heading is opened and "Welcome to the Official BMW Turkey Facebook Page!" statement was shared. Under the Company Overview heading, there is information about BMW Turkey. This is the information that Borusan Otomotiv, which is the partnership of Borusan Holding and Giwa Holding which operates in Germany, has been the distributor of BMW in Turkey since 1984. Under the Products heading, there is a sharing about BMW automobiles. On the other hand, under the title of Milestones; since it was founded in 1916, developments that were important until the year of 2007 were shared.

- There is an About Us section on the official Facebook ${ }^{\mathrm{TR}}$ page of Audi. Under the About title, information about the establishment of the company in 1899 was shared. Under Mission title, there are shares related to the mission of the Audi Turkey Facebook page and its purpose of establishment. It is stated that Facebook page of Audi Turkey has been set up to share up-to-date information from the world of Audi, innovations and visuals about the products, events organized by Doğuş Otomotiv and Audi's most creative movies with Audi fans. Under the Contact information title; @auditurkiye is given in order to send messages and its corporate website address http://www.audi.com.tr is included. Under the More information title, in About section a definition as "Official Facebook page of Audi Turkey, the perfect combination of technology and design" is included. Again in the Company Overview section under the same title, information about the founding year and its founder, the meaning of the company name and its history was shared. It also includes details related to its general philosophy and motto. Under the Milestones section, there are shares of the names and histories of Audi car models since its establishment in 1899 until 2012.

- There is an About Us section on the official Facebook ${ }^{\mathrm{TR}}$ page of Porsche. In the corporate information section under the heading About, it is stated that it was founded in 1887. Contacts information section contains @porscheturkiye link to send messages and 
http://www.porsche.com.tr corporate web page address. About section under the heading More information, it states that this is the Official Facebook Turkey page of Porsche. In addition, Porsche http://www.porsche.com.tr address is given for Porsche Turkey. In an overview of the company, another division under the same title, there are statements like "Porsche is attraction. It transforms imagination and reliability into reality. This is where Porsche gets its unique power to be lively and attractive. At Porsche, thoughts and plans are formed with this thought that is most prominent in the mind: Return to the future. "Porsche, which set out with "To adapt to the age is our legacy." philosophy is now on Facebook to live with its fans." In the Products section, Boxster, Cayman, 911, Panamera, Cayenne are located. In Our story section, there is a statement: "All you wonder about Porsche, brand new models and the most beautiful videos are on the official page of Porsche Facebook" In the Milestones section, there are chronological details such as the historical development of the products from 1887 to 2012, the achievements of the brand, the opening of Porsche centers and authorized dealers.

- There is an About Us section on the official Facebook ${ }^{\mathrm{TR}}$ page of Land Rover. It was stated in the corporate information under About Us tittle that it was established in 1948. In the Mission section under this heading, details such as technical infrastructure and design features related to Land Rover, and innovations introduced to the market were shared. The Land Rover milestones section provides technical details and specifications for the product and brand and qualifications of the products. Contacts information section contains@landroverturkiye link to send messages and http://www.landrover.com.tr. corporate web page address. About part in More information section states "Welcome to the Official Land Rover Turkey Facebook Page!" Milestones section contains details including the historical processes such as the product and brand promotions from 1948, the foundation year, until 2012, product details and anniversaries.

In the visual design element heading, it seems that there is no sharing about other brands like in Mercedes-Benz and BMW brands. Under the Commemoration of the Founders title of Mercedes-Benz and Porsche brands it was seen that Mercedes-Benz and Porsche brands share photos and messages related to their founders, while there was no content belonging to their founders in other brands' shares. Under the title of Logo/Logo design, there are shares that highlight the logo and focus on it in the shares of the Mercedes - Benz brand, and in addition, there is a share about the production process of the brand's logo, which is found in Porsche brand but not in others. When we look at the status messages of brands, we see that they all share status messages. Under the special day/national holiday title, it is noteworthy that the national holiday and special day (anniversary day, father's day, world women's day, etc.) are included in the celebration messages. Looking at the share of brands in corporate magazines / publications, it was seen that only Mercedes - Benz brand shares its corporate magazine online and redirects to it.

When we look at the titles in the content category for the product promotion and the related shares made by the brands:

Under the New product promotion title, it is seen that each brand shares content and photo and video content for new product and product series. BMW and Audi shared under the explanation of new benefits of the old product heading, while other brands did not share content in this section. It is noteworthy that all of the brands in the scope of the research have shares under the heading to create interest in the product category. There is no share of brands related to redirecting to the online store / product promotion. There was no press release content in the share of the brands. However, it was seen that brands 
shared brief information (such as information of the event, date of the event, etc.) about their activities prior to them. It is seen that there are no shares related to the new technology of the products in the Land Rover brand but they are found in all other brands. It is worth noting that there are no contents sharing the historical backgrounds of the products in Audi brand but found in other brands. Under the product advertisement title, brands share relevant content except Mercedes - Benz and Audi brands. It is noteworthy that the contents related to the brand's different product and accessory promotions are shared by all brands. In redirecting to the web site, last title in this category, it is observed that there is no redirecting to their official websites in the shares of Audi and Land Rover brands, but there is redirection in other brands. When the headings in the content category for marketing support are examined, In the official Facebook ${ }^{\mathrm{TR}}$ account of the brand, it was seen that the followers of each brand performed likes, comments, share and viewing for the brand-related contents shared by the company. In creating new ways of reaching consumers heading, all brands seemed to organize activities such as contests, lottery, etc. to reach their followers from their Facebook TR account. While Mercedes - Benz and Audi share the sponsorship activities of the brand, other brands do not share the sponsorship activities of the brand. Under the Campaign announcements title, brands shared information about their winter - summer - autumn campaigns they organize and sales discounts for informing consumers and followers of the brands. The activities carried out by the brands (concerts, festivals, corporate trainings, etc.) are shared by each brand. Corporate achievements / award shares are found in all brands except BMW brand. Looking at the titles in the content sharing category for sales support, it is seen that every brand other than Porsche shares messages that contain invitations to shops / showrooms in terms of creating store / showroom traffic. It is worth noting that all brands except Audi brand invite their followers and customers to test drive to experience their automobiles in the Facebook ${ }^{\mathrm{TR}}$ application. It was observed that brands do not share information about product designers (who they are, products design processes, stories, etc.). Again in this category, it was observed that Mercedes Benz and Porsche brands redirect to their service applications, while others don't redirect to their service applications.

The Instagram coding scheme applied in the qualitative section of the research and the findings obtained are shown in Table 5.

In Instagram shares of Mercedes-Benz brand, corporate success / award content is heavily involved in October. In this title, there is content about corporate achievements such as Crystal Apple, Rally Championship. Contents of the technical infrastructure were shared by the brand in March - May, July - October, and November. These shares are the photo and video content of the technical specifications and infrastructures of the products. Under the title of the historical development of brand's product, there are contents of old photographs and videos related to the historical development of the products. According to the other months, the related content was found to be shared more often in February, August and September. New product / series promotions for the brand have been shared almost every month between February 2016 and January 2017. Compared to other categories, content related to new product / series promotion was shared more intensively. The contents related to the design / production details of the products of Mercedes Benz brand consist of interior and exterior design details of the products and they are shared between April - October and January. 
Online Journal of Communication and Media Technologies, 2019

Table 5. Findings for Official Instagram Accounts

\begin{tabular}{|c|c|c|c|c|c|}
\hline \multicolumn{6}{|l|}{ Content of Photo } \\
\hline \multirow[t]{2}{*}{ Categories } & \multicolumn{5}{|c|}{ Brand Names } \\
\hline & Mercedes-Benz & BMW & Audi & Porsche & Land Rover \\
\hline \multicolumn{6}{|l|}{ Product } \\
\hline $\begin{array}{l}\text { Corporate Achievement / } \\
\text { Celebration }\end{array}$ & Present / 6 & Absent & Present / 3 & Present / 10 & Present / 4 \\
\hline Special Days/National Holidays & Present / 12 & Present / 13 & Present / 9 & Present / 9 & Present / 13 \\
\hline Employees & Absent & Absent & Absent & Absent & Absent \\
\hline Building/Service & Absent & Absent & Absent & Present / 1 & Absent \\
\hline Technical Infrastructure & Present / 13 & Present / 11 & Present / 2 & Present / 11 & Present/17 \\
\hline Brand Owners & Absent & Absent & Absent & Present / 2 & Absent \\
\hline $\begin{array}{l}\text { Historical Background Of The } \\
\text { Product }\end{array}$ & Present/17 & Present / 7 & Absent & Present / 13 & Present / 4 \\
\hline New product / Series Introduction & Present / 131 & Present / 97 & Present / 85 & Present / 35 & Present / 75 \\
\hline Design / Production & Present/17 & Present / 12 & Present / 4 & Present / 10 & Present / 24 \\
\hline Test Drive & Present / 5 & Present / 3 & Absent & Absent & Present / 1 \\
\hline Activities (CSR, festivals. etc.) & Present / 44 & Present / 16 & Present / 13 & Present / 11 & Present / 7 \\
\hline $\begin{array}{l}\text { Instagram Activities (contest, } \\
\text { draw, etc.) }\end{array}$ & Present / 19 & Present / 7 & Present / 18 & Present / 9 & Present / 4 \\
\hline Sponsorship Works & Present / 3 & Present / 1 & Absent & Present / 1 & Absent \\
\hline Brand's Promotional Products & Present / 2 & Absent & Present / 3 & Present / 7 & Absent \\
\hline $\begin{array}{l}\text { Online service (online product, } \\
\text { service) Redirecting }\end{array}$ & Present / 6 & Absent & Present / 6 & Present / 3 & Absent \\
\hline $\begin{array}{l}\text { Commemoration of Founders / } \\
\text { Designers }\end{array}$ & Absent & Absent & Absent & Absent & Absent \\
\hline Campaign announcements & Present / 1 & Present / 2 & Present / 4 & Absent & Present / 3 \\
\hline Store / Showroom & Present / 15 & Present / 6 & Present / 10 & Absent & Present / 1 \\
\hline \multicolumn{6}{|c|}{ Instagram Page } \\
\hline \multirow[t]{2}{*}{ Categories } & \multicolumn{5}{|c|}{ Brand Names } \\
\hline & Mercedes-Benz & BMW & Audi & Porsche & Land Rover \\
\hline Number of Posts & 309 & 177 & 164 & 120 & 172 \\
\hline Photograph & 274 & 150 & 139 & 93 & 156 \\
\hline Video & 55 & 27 & 30 & 53 & 22 \\
\hline Likes & 802,191 & 447,855 & 414,629 & 37,742 & 100,279 \\
\hline Comment & 8,006 & 3407 & 3236 & 466 & 595 \\
\hline View & 839,791 & 419,953 & 477,648 & 111043 & 76017 \\
\hline Number Of Followers & 257,000 & 257,000 & 264,000 & 70,800 & 76,500 \\
\hline Number of Followings & 11 & Absent & 21 & Absent & 1 \\
\hline Logo & Present / 6 & Present & Present & Present & Present \\
\hline URL & Absent & Absent & 7 & 3 & 1 \\
\hline Contact & Present & Present & Present & Present & Present \\
\hline
\end{tabular}

Test drive invitation / experience activities for the brand's customers and followers were made in April-October and November. When we look at the shares in the Activities title, it is noteworthy that the activities of the brand were shared almost every month during the research and more content was shared than the other months especially in May, September and October. It is seen that the activities that brand offers in the official Instagram account for its customers and followers are shared almost every month and at the same rate. Contents of sponsorship activities were seen to cover being the official automobile sponsor of Zorlu Performing Arts Center and they were seen to be shared in April, May and January. The contents of the promotional products / accessories of the brand consist of wind deflector and Mercedes - Benz Collection products. Shares in the title of accessories belonging to the brand were made in July and December. In the heading of redirecting to Online services, It has been observed that the shares, which include redirecting to applications through WhatsApp, benimmercedesim.com in online environments were made in May - July and October. The contents of the announcements 
of the campaigns that the brand has organized about its products include sales, discounts for the services of the brand. These contents were only shared in July. Contents for which there are redirecting for the store / showroom where the products are located consist of invitations for the stores and showrooms of the brand and It is noteworthy that these shares increased between July and September. It is observed that the relevant shares where the brand's logo is in the foreground were made in February - March and July August.

It is seen that the technical infrastructure features of the BMW brand cars were shared in August - October and December - January. Shares related to the historical development of the products include contents of the historical samples of the cars belonging to the brand. Shares were made in March - May, September and November. Looking at the brand's new product/series promotional content, it is noteworthy that there are more shares of the brand's new cars or car series compared to titles in other categories. Related shares were made in approximately the same number throughout the months within the research. In the title of design / production details, the number of shares in which the interior and exterior design details of the products of the brand are presented are approximately the same in every month. Test drive invitation / experience that the BMW brand has arranged for its customers and followers were shared in July, August and October. It is observed that the shares related to the activities realized are distributed in similar proportions in months. It is seen in the Instagram account that the activities for customers and followers are organized in December and January. Content of the brand's promotional products / accessories was shared in October. The contents of the announcements of the campaigns planned by the BMW brand cover shares of campaigns such as winter, autumn, discounts organized by the brand for its cars and these were seen to be shared in November and December. Shares of the brand's store I show room redirectings include invitation messages for the followers of the brand to the store / showrooms and it is noteworthy that these were shared only in May and September.

Looking at the corporate success / celebration shares of the Audi brand, it was seen that there were shares of the brand's corporate achievements and awards in May, August and October. It is observed that the technical infrastructure title for the products of the brand includes the shares in which the technical details and infrastructure features of the brand's automobiles are presented and related shares were made in December and January. It is notable that the contents of the new product / series promotions were shared intensively every month. In the design / production content of the brand's products, interior and exterior design details of the brand's cars were included and they were shared in June, August and October. It is seen that the contents for the activities performed by the Audi brand were shared in March, June, July and October, November and January. The activities carried out by the brand through Instagram account consisted of the competitions, draws, which were organized in Instagram application for the followers of the brand, and the activities that enable them to produce comments / ideas about the brand's products and the related content was seen to be shared in August, October, December and January. The title of the brand's promotional products / accessories contains the content of the brand's promotional products and this was shared in August and September. Online service (product, service, etc.) content that is in the redirecting heading consists of redirecting of the brand to its online applications in August, September and October. It was observed that the campaign announcements of the brand were made in September, October and 
November and that these were made up of information related to the campaigns organized for the consumers of the brand. In brand's shares in the store/show room title, there are redirections for the followers and consumers of Audi brand to the stores and showrooms. It shares this redirecting content in June and January.

Porsche brand shares its corporate achievements in June and January in its Instagram application. The brand has a visual share in the contents of the building / service title. It appears that there is almost equal number of shares of the brand's products, including the technical infrastructure details, in every month. When we look at the title of brand owners, the fact that there are messages and photos of brand owners in the shares of the Porsche brand draw attention. The related share was made only in October. It was observed that the contents of the historical past of the products consisted of historical development, production processes and old and new details of the cars of the Porsche brand. The fact that there are more shares in this category compared to other brands is notable. These shares take place in all months except June and July. In the title of new product/series promotion, it can be said that there were frequent shares of the Porsche brand about the new cars and series during the research period except in February 2016 and January 2017. Content related to details of the design and production of the brand's cars was shared in February, March, October, November and January. It was observed that the shares of the activities carried out by the brand in institutional level were realized in Instagram application in March, April, June, July and autumn winter periods (October, November and January). In the title of the Instagram activities of the Porsche Brand; it contains only the activities they organize for the followers of the brand regarding their cars via Instagram and they were observed to be shared in February - May and September - December. It can be said that sponsorship activities of the brand in the Instagram were shared only in May. It was seen that the brand shared content regarding its promotional products / accessories in March and July. Contents of the brand to redirect its followers to its online services were seen to be shared in January, February and March.

In the title of corporate achievement/ celebration of Land Rover brand, there are shares of corporate achievements of the brand and it is observed that these contents were shared with its followers in February and May. Contents of the technical infrastructure and production details of the brand's automobiles show a similar distribution between February and December. Content of the historical development of the products was found between March and May. The brand's new product / series promotions shares are made up of relevant content of the brand's new car series and it was determined that they were shared extensively between the months of February and November. In the title of design / production details, the content of Land Rover brand cars' interior and exterior design details are shared extensively between February and June and August and November. Land Rover invites its users and followers for a test drive experience through Instagram. This invitation content was shared in June. When we look at the shares of the content belonging to the activities carried out by the brand in Instagram application, it is observed that they are shared between February - March and October - November. In the title of Instagram activities, it was determined that there are shares related to activities such as draws, contests organized by the brand in Instagram application for its followers, and related shares were included in February, April and August. In the Campaign announcement heading, it is seen that Land Rover brand shared the announcements of its campaigns such as winter and summer discounts for cars, and these took place in October and December. The Land Rover brand produces 
and shares content for its users and followers in order them to visit its stores and showrooms. It was observed that these organized visits were shared in June.

\section{ASSESSMENT OF THE RESEARCH AND THE RESULT}

As a result of the content analysis, when we look at the social media usage practices of these luxury car brands, it is seen that they share their corporate identity in their official Facebook accounts, but mission and vision sections are more limited in terms of their contents. Recently, with the democratization of luxury and the accessible luxury concept becoming widespread, there have been changes in the structure and nature of luxury consumers. Reaching the luxury brands in social media environments (such as seeing, watching, sharing etc.) that cannot be reached in traditional environments is a remarkable situation. During luxury brand communication period brands, and also in particular luxury brands try to understand social media usage practices. In this sense, luxury brands try to have a clear understanding of "what social media could do for them", and "develop a clear strategy of how they could enhance customers' experience and perceptions of their brands" during this situation (Phan, Thomas \& Heine, 2011: p. 213).

Luxury consumers and followers are also able to reach the luxury brands and obtain the information they are interested about luxury brands by socializing in these environments as well. Therefore, luxury brands' sharing's the details of their corporate identity and information is of great importance at this point. In addition to these, it has been seen that brands use social media more intensively in new products / series promotions, creating interest in product categories, introducing new technologies of their products and introducing accessories / promotions related to the brand in comparison to other headings in the category chart. On the other hand, it can be said that there are no press release shares related to their products and there is a limited number of redirecting shares to their corporate websites. It is especially noteworthy that in the Porsche brand's shares there is emphasis on the history and design details of their products. In social media usage practices of these brands, it was observed that there are activities (such as drawing, contest) organized in social media environments to create new ways of reaching consumers and followers, as well as marketing-oriented shares about activities (such as CSR, other institutional activities) that are realized at the brand's corporate-level.

As a result, when we look at the social media usage practices of luxury automobile brands included in the research in their Instagram shares during the given period of time, we see shares of contents about the corporate achievements / news, special day / national holiday celebrations, the technical infrastructure of the products, the brand's corporatelevel activities, the events they organize in the Instagram account for customers and followers in each brand. Therefore, it can be said that the social media usage practices of each of these brands in the given dates focused extensively on shares in this direction. On the other hand, none of the brands within the scope of the research have shares about the founders / designers and employees of the brand.

\section{RECOMMENDATIONS}

- Content analysis performed can be applied periodically. Particularly, a separate study can be carried out on the content that the luxury brands share in social media environments during campaign periods.

- In-depth interviews can be conducted on the use of social media, including relevant departments and managers of luxury brands at the institutional level, in order to contribute to the luxury brand literature and professional practice areas. 
- Considering the place where luxury comes in parallel with the evolving technologies and changing market conditions, ability to access luxury in social media environments, luxury becoming more democratic and the concept of new luxury are of particular importance for potential followers who do not consume luxury products. Therefore, it is important for luxury brand managers to take this reality into account when determining strategies for social media environments.

- In social media usage practices of luxury brands, perhaps a little more detailed information can be provided in the presentation of corporate identities. In addition, studies can be carried out on the samples of the same brand in different countries.

- In social media applications and digital brand works of luxury brands, being particularly sensitive and more careful about digital ethics can be considered as a positive value for their brand works.

\section{ACKNOWLEDGEMENTS}

This article is derived from a dissertation thesis entitled "The relationship between social media and brand loyalty: a research based on luxury automobile brans" in Ege University Institute of Social Sciences, 2018 January, Izmir, Turkey.

\section{REFERENCES}

Ahmed, O. H, Lee, H., \& Struik, L. L. (2016). A Picture Tells a Thousand Words: A Content Analysis of Concussion-Related Images Online. Phys Ther Sport, 21, 82-6. https://doi.org/10.1016/j.ptsp.2016.03.001

Akyol, A. Ç., Akyol, M., \& Yılmaz, A. (2014). Yeni Medya Araçlarında Görsel İletişim: Otomobil Markalarının Sosyal Medya Kullanımları Üzerine Bir İnceleme [In Turkish]. Selçuk İletişim Dergisi, 8, 119-131.

Balcı, A. (2011). Sosyal Bilimlerde Araştırma Yöntem, Teknik ve İlkeler [In Turkish]. Ankara: Pegem.

Ciftci, D., \& Evren, D. B. (2018). A New Creative Culture Example: The Case of the 'What will be Happen News Bulletin' in North Cyprus. Online Journal of Communication and Media Technologies, 8, 385-398. https://doi.org/10.12973/ojcmt/3959

Eginli, A. T., \& Ozmelek, N. (2018). Interpersonal Communication in Social Networking Sites: An Investigation in the Framework of Uses and Gratification Theory. Online Journal of Communication and Media Technologies, 8, 81-104.

Jin, S.-A. A. (2012). The Potential of Social Media for Luxury Brand Management. Marketing Intelligence \& Planning, $\quad 30, \quad 687-699$. https://doi.org/10.1108/02634501211273805

Kim, A. J., \& Ko, E. (2010). Impacts of Luxury Fashion Brand's Social Media Marketing on Customer Relationship and Purchase Intention. Journal of Global Fashion Marketing, 1, 164-171. https://doi.org/10.1080/20932685.2010.10593068

Kim, A. J., \& Ko, E. (2012). Do Social Media Marketing Activities Enhance Customer Equity? An Empirical Study of Luxury Fashion Brand. Journal of Business Research, 65, 1480-1486. https://doi.org/10.1016/j.jbusres.2011.10.014

Meikle, G. (2016). Social Media: Communication, Sharing and Visibility. London: Routledge. https://doi.org/10.4324/9781315884172

Nueno, J. L., \& Quelch, J. A. (1998). The Mass Marketing of Luxury. Business Horizons, 41: 62-63. https://doi.org/10.1016/S0007-6813(98)90023-4 
Phan, M., Thomas, R., \& Heine, K. (2011). Social Media and Luxury Brand Management: The Case of Burberry. Journal of Global Fashion Marketing, 2, 213-222. https://doi.org/10.1080/20932685.2011.10593099

Yıldırım, A., \& Şimşek, H. (2013). Sosyal Bilimlerde Nitel Araştırma Yöntemleri [In Turkish]. Ankara: Seçkin.

https://en.oxforddictionaries.com/definition/luxury Retrieved on 11.06.2018.

http://luxurysociety.com/articles/2014/10/2014s-best-global-luxury-brands Retrieved on 11.06.2018.

https://www.luxurysociety.com/en/articles/2018/05/social-media-powering-new-retail-

wave Retrieved on 11.06.2018.

https://www.socialmediadelivered.com/blog/2015/11/13/top-10-luxury-brands-on-socialmedia Retrieved on 11.06.2018.

http://www.tdk.gov.tr/index.php?option=com_gts\&arama=gts\&guid=TDK.GTS.5b1f7a93 371f56.47236444 Retrieved on 11.06.2018.
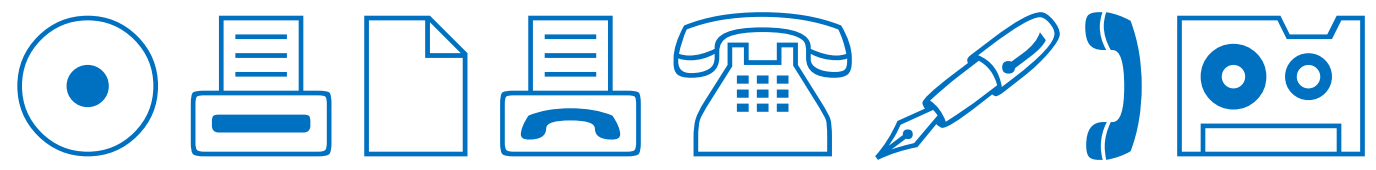